\title{
Commentary
}

\section{SDF-1:CXCR4 Axis Is Fundamental for Tissue Preservation and Repair}

\author{
Marc S. Penn \\ From the Skirball Laboratory for Cardiovascular Cellular \\ Therapeutics, the Department of Stem Cell Biology and \\ Regenerative Medicine, and the Department of Cardiovascular \\ Medicine, Heart and Vascular Institute, Cleveland Clinic, \\ Cleveland, Ohio
}

Adult stem cell therapy has demonstrated the potential for tissue preservation and repair in multiple organ systems including the heart, ${ }^{1}$ liver, ${ }^{2}$ brain, ${ }^{3}$ skin, ${ }^{4}$ and kidney. ${ }^{5}$ In some organ systems, such as the liver, there is evidence of real regeneration, ${ }^{6}$ whereas in other organ systems, such as the heart, there is little evidence for tissue regeneration. ${ }^{7,8}$ Regardless of whether tissue is regenerated in a given organ system, consistent evidence exists across all organ systems for modulation of cell death, leading to preservation of organ-specific tissue function. The similarity of tissue preservation across systems suggests that there may exist a common mechanism of use for adult stem cell therapy; furthermore, the findings that conditioned media from adult stem cells led to tissue preservation suggested that the effect was due, at least in part, to paracrine factor expression by the adult stem cells. ${ }^{8,9}$

Early in the investigation of the mechanisms related to stem cell-based tissue repair, the stromal cell-derived factor-1 (SDF-1):CXCR4 axis was identified as a key factor in the recruitment of stem cells to areas of tissue injury in multiple organ systems. ${ }^{10-12}$ These findings led us to propose that the reestablishment of SDF-1 expression late after tissue injury could serve as a strategy to induce tissue repair; ${ }^{10,13}$ this hypothesis is now the focus of an on-going clinical trial in patients with chronic heart failure (NCT01082094, clinicaltrials.gov). More recently, studies by our group and others have demonstrated that the expression of SDF-1 at the time of acute injury induces the recruitment of endogenous tissue-specific stem cells ${ }^{14}$ as well as direct preservation of end-organ cells such as cardiac myocytes. ${ }^{8}$

Further demonstrating the importance of the SDF-1 in tissue repair, in this issue of the journal, Otsuka et al ${ }^{15}$ demonstrate the role of SDF-1 in inhibiting photoreceptor cell loss in retinal detachment. These investigators quantified the levels of vascular endothelial growth factor and
SDF-1 in the vitreous of patients with retinal detachment $(\mathrm{RD})$ and proliferative diabetic retinopathy as well as other pathologies. Vascular endothelial growth factor and SDF-1 levels are increased in proliferative diabetic retinopathy; ${ }^{16,17}$ however, only SDF-1 levels were increased in $\mathrm{RD}$. Interestingly, the up-regulation of SDF-1 in RD did not lead to proliferation of the vasculature of the retina. Consistent with the up-regulation of SDF-1 in response to $\mathrm{RD}$ is the correlation of vitreous SDF-1 levels with the extent and duration of RD.

The investigators took their observation of increased SDF- 1 in the vitreous of patients with RD and nicely investigated the effects of SDF-1 in the R28 retinal precursor cell line and a rat model of RD. Their data demonstrate that there is minimal SDF-1 expression in the normal eye but that within 3 days of experimentally induced $\mathrm{RD}$ there is increased SDF-1 expression in the anti-glial fibrillary acidic protein-positive astrocytes. Based on the known biology of the SDF-1, the increased expression of SDF-1 in the vitreous could have multiple effects including recruitment of bone marrow-derived stem cells and local inhibition of cell death in CXCR4-expressing cells.

The lack of vascular changes associated with increased SDF-1 expression in patients with RD suggests that SDF-1 expression is not associated with significant recruitment of bone marrow-derived endothelial progenitor cells because it is associated with SDF-1-mediated myocardial healing. ${ }^{8,10}$ Rather, the mechanism of SDF-1mediated healing or tissue preservation in the eye seems to be more related to that seen in the skin, the healing of which is also not associated with vascular growth. ${ }^{18}$

Otsuka et $\mathrm{al}^{15}$ demonstrate that SDF-1 expression in the eye in the setting of RD is associated with preservation of photoreceptors in the outer nuclear layer. Further demonstrating that the effects of SDF-1 are specific in response to injury, inhibition of SDF-1 signaling in the normal eye had no

Supported by the Skirball Foundation.

Accepted for publication August 13, 2010

CME Disclosure: M.S.P. is listed on patent applications filed by the Cleveland Clinic Foundation for the use of SDF-1 and CXCR4 for tissue repair.

Address reprint requests to Marc S. Penn, M.D., Ph.D., Skirball Laboratory for Cardiovascular Cellular Therapeutics, Departments of Cardiovascular Medicine and Stem Cell Biology, J2-131, 9500 Euclid Ave., Cleveland, OH 44195. E-mail: pennm@ccf.org 

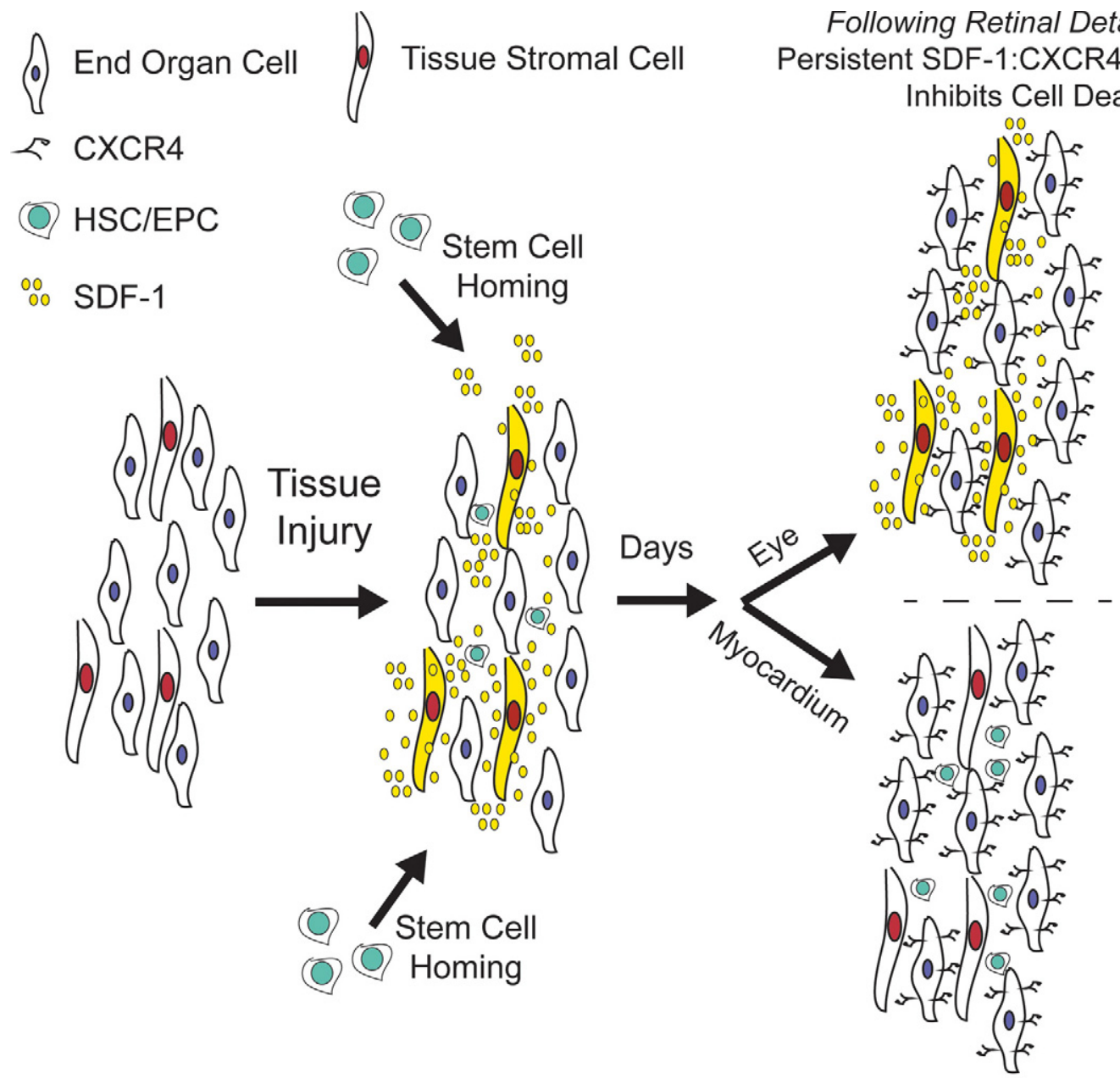

\section{Following Myocardial Infarction \\ Early - SDF-1 recruits cardiac and bone marrow stem cells Late CXCR4 expression renders heart responsive to stem cells}

Figure 1. Schematic representation of the effects of tissue injury on SDF-1:CXCR4 expression and the local and remote effects of modulating their local expression.

effects on cells in the outer nuclear layer. Of importance, the specificity of the SDF-1 response was mediated by the expression of CXCR4 by photoreceptors in the outer nuclear layer. CXCR4 expression in the normal retina was limited to the ganglion cell and the inner nuclear layers; however, in response to $\mathrm{RD}$, there was significant CXCR4 expression in the outer nuclear layer and photoreceptor inner segments of the detached retina. The importance of the SDF-1:CXCR4 axis on cell survival was confirmed in studies using the R28 retinal precursor cell line in the setting of serum starvation, similar to what we have previously demonstrated in the setting of hypoxia and serum starvation using mesenchymal stem cells. ${ }^{8}$

Perhaps directly in the eye ${ }^{15}$ and $\operatorname{skin}^{18}$ and more circuitously in other organ systems including the heart ${ }^{10}$ and brain, ${ }^{19}$ up-regulation of the SDF-1:CXCR4 axis is a fundamental response to tissue injury and modulating SDF $-1^{8}$ and $\mathrm{CXCR} 4^{20}$ expression can serve as a strategy to preserve and restore end-organ function. The se- quence of events after tissue injury is generalized in Figure 1: i) After tissue injury there is a local up-regulation of SDF-1 expression. The increased SDF-1 expression leads to homing of endogenous and bone marrow-derived stem cells in some organ system. ii) The end-organ cells up-regulate CXCR4 expression. The local up-regulation of CXCR4 can lead to cellular dysfunction ${ }^{21}$ but renders the cell responsive to SDF-1-mediated survival.

As delineated in Figure 1, the up-regulation of SDF-1 can lead to stem cell homing and engraftment that seems to be associated with neovascularization. In the absence of stem cell homing as seen in this study by Otsuka et $\mathrm{al}^{15}$ and in recent studies on SDF-1-mediated surgical wound healing, ${ }^{18}$ SDF-1 expression does not seem to induce neovascularization.

One recurring question regarding the importance of the SDF-1:CXCR4 axis in tissue repair is if the axis is so critical, why does the up-regulation of CXCR4 on endorgan cells often occur at a time when SDF-1 expression 
is declining ${ }^{22}$ ? We have recently demonstrated that although SDF-1:CXCR4 coexpression is required for normal cardiac development, ${ }^{23}$ once cardiac myocyte fate is determined, CXCR4 expression is no longer required. ${ }^{24}$ Thus, one hypothesis is that because SDF-1:CXCR4 expression is intimately involved in tumor metastases, ${ }^{25,26}$ evolution has favored mammals that, in adulthood, have SDF-1 expression temporally misaligned with organ CXCR4 expression.

The study of Otsuka et $\mathrm{al}^{15}$ extends the end-organ systems involved in SDF-1:CXCR4 tissue preservation and repair. It also raises some important and interesting questions for future studies. In particular, the eye in response to RD, like the bone marrow, seems to have sustained SDF-1 expression. In most organ systems studied to date, SDF-1 is rapidly up- and then downregulated. ${ }^{22}$ Previous studies have suggested that SDF-1 expression in stroke and myocardial infarction is due to modulation of intracellular hypoxia-inducible factor- $1 \alpha^{20}$ The lack of vascular endothelial growth factor expression in the vitreous of RD suggests that hypoxia-inducible factor- $1 \alpha$ is not responsible for SDF-1-mediated expression in RD. Thus, the mechanism of SDF-1 up-regulation in $\mathrm{RD}$ remains to be elucidated.

In summary, the study by Otsuka et a ${ }^{15}$ elucidates an important role for SDF-1 expression in preservation of photoreceptors and the outer nuclear layer of the eye after retinal detachment. These findings suggest that CXCR4 expression in the eye is modulated in injury and that exogenous SDF-1 delivery may serve as a strategy to further preserve tissue structure during healing. Future studies need to be focused not only on the therapeutic potential of SDF-1 in ocular disease states but also on the molecular mechanisms associated with SDF-1 up-regulation in the eye after retinal detachment as well as the mechanisms associated with specific CXCR4 expression in specific tissue layers of the eye.

\section{References}

1. Schächinger V, Erbs S, Elsasser A, Haberbosch W, Hambrecht R, Holschermann H, Yu J, Corti R, Mathey DG, Hamm CW, Suselbeck T, Assmus B, Tonn T, Dimmeler S, Zeiher AM: Intracoronary bone marrow-derived progenitor cells in acute myocardial infarction. $N$ Engl J Med 2006, 355:1210-1221

2. Vassilopoulos G, Wang PR, Russell DW: Transplanted bone marrow regenerates liver by cell fusion. Nature 2003, 422:901-904

3. Nakano-Doi A, Nakagomi T, Fujikawa M, Nakagomi N, Kubo S, Lu S, Yoshikawa H, Soma T, Taguchi A, Matsuyama T: Bone marrow mononuclear cells promote proliferation of endogenous neural stem cells through vascular niches after cerebral infarction. Stem Cells 2010, 28:1292-1302

4. Snippert HJ, Haegebarth A, Kasper M, Jaks V, van Es JH, Barker N, van de Wetering $M$, van den Born M, Begthel H, Vries RG, Stange DE, Toftgard R, Clevers H: Lgr6 marks stem cells in the hair follicle that generate all cell lineages of the skin. Science 2010, 327:1385-1389

5. Choi SJ, Kim JK, Hwang SD: Mesenchymal stem cell therapy for chronic renal failure. Expert Opin Biol Ther 2010, 10:1217-1226

6. Lagasse E, Connors H, Al Dhalimy M, Reitsma M, Dohse M, Osborne L, Wang X, Finegold M, Weissman IL, Grompe M: Purified hematopoietic stem cells can differentiate into hepatocytes in vivo. Nat Med 2000, 6:1229-1234

7. Murry CE, Soonpaa $M H$, Reinecke $H$, Nakajima $H$, Nakajima $H O$, Rubart M, Pasumarthi KB, Virag JI, Bartelmez SH, Poppa V, Bradford
G, Dowell JD, Williams DA, Field LJ: Haematopoietic stem cells do not transdifferentiate into cardiac myocytes in myocardial infarcts. Nature 2004, 428:664-668

8. Zhang M, Mal N, Kiedrowski M, Chacko M, Askari AT, Popovic ZB, Koc ON, Penn MS: SDF-1 expression by mesenchymal stem cells results in trophic support of cardiac myocytes after myocardial infarction. FASEB J 2007, 21:3197-3207

9. Gnecchi M, Zhang Z, Ni A, Dzau VJ: Paracrine mechanisms in adult stem cell signaling and therapy. Circ Res 2008, 103:1204-1219

10. Askari A, Unzek S, Popovic ZB, Goldman CK, Forudi F, Kiedrowski M, Rovner A, Ellis SG, Thomas JD, DiCorleto PE, Topol EJ, Penn MS: Effect of stromal-cell-derived factor-1 on stem cell homing and tissue regeneration in ischemic cardiomyopathy. Lancet 2003, 362:697-703

11. Rosenkranz K, Kumbruch S, Lebermann K, Marschner K, Jensen A, Dermietzel R, Meier C: The chemokine SDF-1/CXCL12 contributes to the 'homing' of umbilical cord blood cells to a hypoxic-ischemic lesion in the rat brain. J Neurosci Res 2010, 88:1223-1233

12. Stokman G, Stroo I, Claessen N, Teske GJ, Florquin S, Leemans JC: SDF-1 provides morphological and functional protection against renal ischaemia/reperfusion injury. Nephrol Dial Transplant 2010, doi: 10.1093/ndt/gfq311

13. Deglurkar I, Mal N, Mills WR, Popovic ZB, McCarthy P, Blackstone $\mathrm{EH}$, laurita KR, Penn MS: Mechanical and electrical effects of cellbased gene therapy for ischemic cardiomyopathy are independent. Hum Gene Ther 2006, 17:1144-1151

14. Unzek S, Zhang M, Mal N, Mills WR, Laurita KR, Penn MS: SDF-1 recruits cardiac stem cell like cells that depolarize in vivo. Cell Transplant 2007, 16:879-886

15. Otsuka H, Arimura N, Sonoda S, Nakamura M, Hashiguchi T, Maruyama I, Nakao S, Hafezi-Moghadam A, Sakamoto T: Stromal cellderived factor-1 is essential for photoreceptor cell protection in retinal detachment. Am J Pathol 2010, 177:2268-2277

16. Djuric Z, Sharei V, Rudofsky G, Morcos M, Li H, Hammes HP, Nawroth PP, Bierhaus A, Humpert PM, Jonas JB: Association of homozygous SDF-1 3'A genotype with proliferative diabetic retinopathy. Acta Diabetol 2010, 47:79-82

17. Madlambayan GJ, Butler JM, Hosaka K, Jorgensen M, Fu D, Guthrie SM, Shenoy AK, Brank A, Russell KJ, Otero J, Siemann DW, Scott EW, Cogle CR: Bone marrow stem and progenitor cell contribution to neovasculogenesis is dependent on model system with SDF-1 as a permissive trigger. Blood 2009, 114:4310-4319

18. Rabbany SY, Pastore J, Yamamoto M, Miller T, Rafii S, Aras R, Penn MS: Continuous delivery of stromal cell-derived factor-1 from alginate scaffolds accelerates wound healing. Cell Transplant 2010, 19:399-408

19. Wang F, Yasuhara T, Shingo T, Kameda M, Tajiri N, Yuan WJ, Kondo A, Kadota T, Baba T, Tayra JT, Kikuchi Y, Miyoshi Y, Date I: Intravenous administration of mesenchymal stem cells exerts therapeutic effects on parkinsonian model of rats: focusing on neuroprotective effects of stromal cell-derived factor-1alpha. BMC Neurosci 2010, 11:52-60

20. Tang YL, Zhu W, Cheng M, Chen L, Zhang J, Sun T, Kishore R, Phillips MI, Losordo DW, Qin G: Hypoxic preconditioning enhances the benefit of cardiac progenitor-cell therapy for treatment of myocardial infarction by inducing CXCR4 expression. Circ Res 2009, 104:1209-1216

21. Pyo RT, Sui J, Dhume A, Palomeque J, Blaxall BC, Diaz G, Tunstead J, Logothetis DE, Hajjar RJ, Schecter AD: CXCR4 modulates contractility in adult cardiac myocytes. J Mol Cell Cardiol 2006, 41:834-844

22. Penn MS: Importance of the SDF-1:CXCR4 axis in myocardial repair. Circ Res 2009, 104:1133-1135

23. Nelson TJ, Faustino RS, Chiriac A, Crespo-Diaz R, Behfar A, Terzic A: $\mathrm{CXCR} 4^{+} / \mathrm{FLK}-1^{+}$biomarkers select a cardiopoietic lineage from embryonic stem cells. Stem Cells 2008, 26:1464-1473

24. Agarwal U, Ghalayini W, Dong F, Weber K, Zou YR, Rabbany SY, Rafi S, Penn MS: Role of cardiac myocyte CXCR4 expression in development and left ventricular remodeling after acute myocardial infarction. Circ Res 2010, doi: 0.1161/CIRCRESAHA.110.223289

25. Lee HJ, Kim SW, Kim HY, Li S, Yun HJ, Song KS, Kim S, Jo DY Chemokine receptor CXCR4 expression, function, and clinical implications in gastric cancer. Int $\mathrm{J}$ Oncol 2009, 34:473-480

26. Richert MM, Vaidya KS, Mills CN, Wong D, Korz W, Hurst DR, Welch DR: Inhibition of CXCR4 by CTCE-9908 inhibits breast cancer metastasis to lung and bone. Oncol Rep 2009, 21:761-767 